\title{
BioSearch: an in-house developed lab information management system for center of excellence in genomic medicine research
}

Sajjad Karim*, Mona SZ Al-Kharraz, Abdelbaset S Buhmeida, Mamdooh A Gari, Adeel GA Chaudhary, Adel M Abuzenadah, Mohammed H Al-Qahtani

From 2nd International Genomic Medical Conference (IGMC 2013)

Jeddah, Kingdom of Saudi Arabia. 24-27 November 2013

\section{Background}

Databases and biobanks are developed in relation to a research question having its own strategy and specific demands on quality and annotation of the collected samples, resulting in multiple designs according to the different possible goals [1]. Translational research is

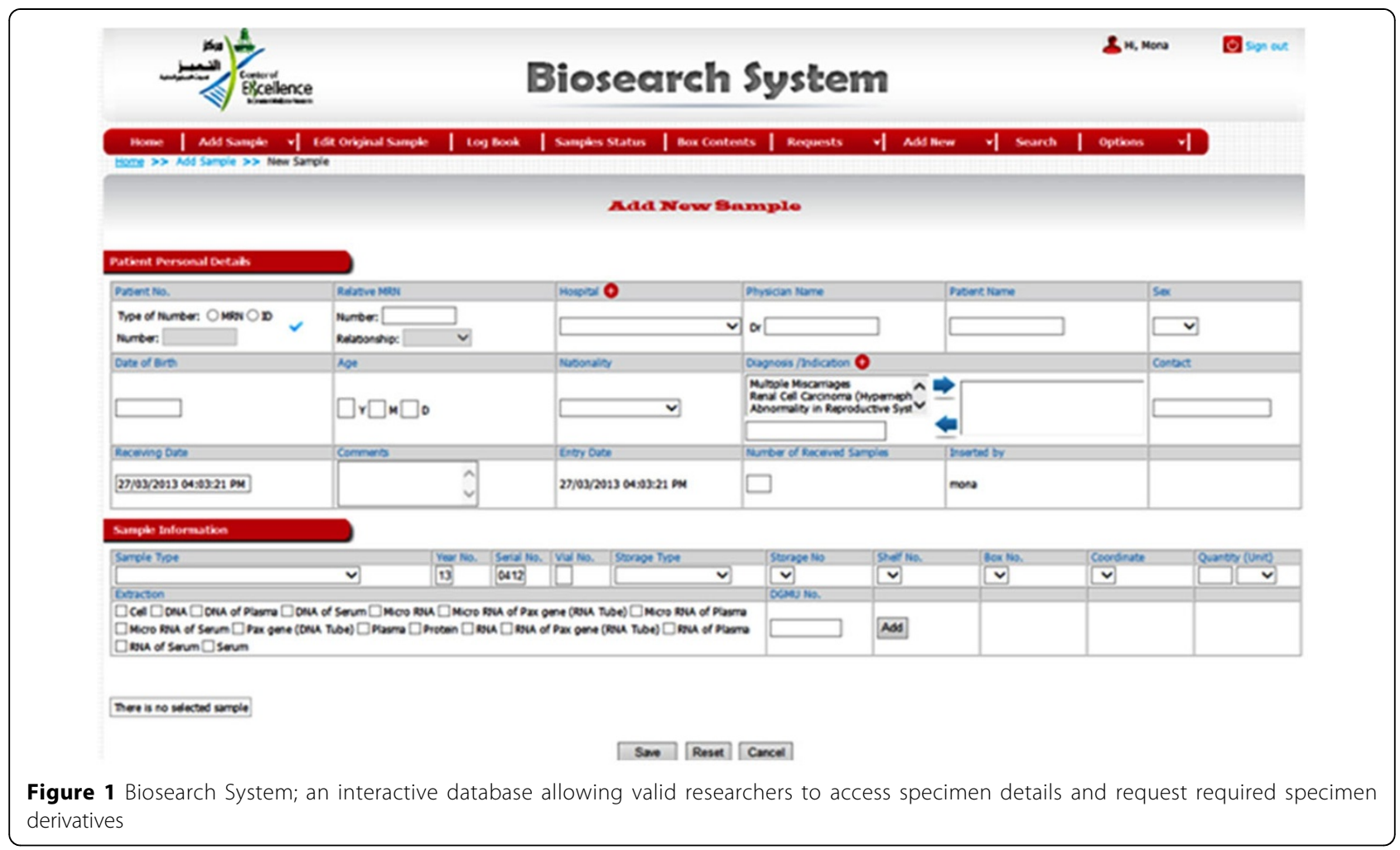

\footnotetext{
* Correspondence: skarim1@kau.edu.sa

Center of Excellence in Genomic Medicine Research, King Fahd Medical

Research Center, King Abdulaziz University, PO Box 80216, Jeddah 21589, 
highly dependent on large series of cases including high quality samples and their associated data.

\section{Materials and methods}

We used ASP.NET as front-end tool, SQL Server Management Studio as back-end tool, and JavaScript and Ajax control toolkit for client-side purpose.

\section{Results}

We successfully developed an in-house Clinical Database and Biobank Management System called BioSearch, a disease-oriented general Biobank, with the goals correspond to disease biomarkers and drug target discovery through prospective and/or retrospective collections of samples and their derivates (DNA/RNA/proteins), usually associated with clinical data (Figure 1). BioSearch manages samples and clinical data of more than 5,000 patients collected between 2005 and 2013. It is composed of two well-connected units: Clinical database, a webbased database for clinical data associated with collected samples and Biobank Management System, a locally hosted database to manage the samples and their derivatives. Presently BioSearch is acting as a backbone for high-throughput genomic studies of CEGMR involved in translational research and personalized medicine.

\section{Conclusions}

In conclusion, "BioSearch" is a platform independent highly flexible web-based user friendly system allowing clinician, researchers and biobank staff to submit, store and retrieve samples and their associated clinical information. In future, we plan to extend its capabilities by implementing new plug-in devoted to experimental research data and bioinformatics for data analysis.

Authors would like to acknowledge the KACST, Riyadh, Saudi Arabia (Project ID: 10-BIO1258-03 and 10BIO107303) for funding the research.

Published: 2 April 2014

\section{Reference}

1. Riegmana PHJ, Morente MM, Betsou F, de Blasio P, Geary P: Biobanking for better healthcare Molecular Oncology. 2000, 2:213-222.

doi:10.1186/1471-2164-15-S2-P41

Cite this article as: Karim et al: BioSearch: an in-house developed lab information management system for center of excellence in genomic medicine research. BMC Genomics 2014 15(Suppl 2):P41.

\section{Submit your next manuscript to BioMed Central} and take full advantage of:

- Convenient online submission

- Thorough peer review

- No space constraints or color figure charges

- Immediate publication on acceptance

- Inclusion in PubMed, CAS, Scopus and Google Scholar

- Research which is freely available for redistribution

Submit your manuscript at www.biomedcentral.com/submit 